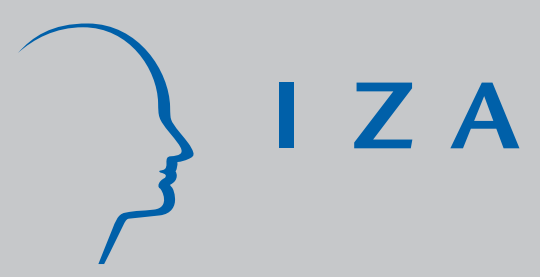

IZA DP No. 879

Entrepreneurial Ventures and Wage Differentials Between Germans and Immigrants

Amelie Constant

Yochanan Shachmurove

September 2003 


\title{
Entrepreneurial Ventures and Wage Differentials Between Germans and Immigrants
}

\author{
Amelie Constant \\ University of Pennsylvania and IZA Bonn \\ Yochanan Shachmurove \\ City University of New York \\ and University of Pennsylvania
}

\section{Discussion Paper No. 879 September 2003}

\author{
IZA \\ P.O. Box 7240 \\ D-53072 Bonn \\ Germany \\ Tel.: +49-228-3894-0 \\ Fax: +49-228-3894-210 \\ Email: iza@iza.org
}

\begin{abstract}
This Discussion Paper is issued within the framework of IZA's research area Mobility and Flexibility of Labor. Any opinions expressed here are those of the author(s) and not those of the institute. Research disseminated by IZA may include views on policy, but the institute itself takes no institutional policy positions.
\end{abstract}

The Institute for the Study of Labor (IZA) in Bonn is a local and virtual international research center and a place of communication between science, politics and business. IZA is an independent, nonprofit limited liability company (Gesellschaft mit beschränkter Haftung) supported by Deutsche Post World Net. The center is associated with the University of Bonn and offers a stimulating research environment through its research networks, research support, and visitors and doctoral programs. IZA engages in (i) original and internationally competitive research in all fields of labor economics, (ii) development of policy concepts, and (iii) dissemination of research results and concepts to the interested public. The current research program deals with (1) mobility and flexibility of labor, (2) internationalization of labor markets, (3) welfare state and labor market, (4) labor markets in transition countries, (5) the future of labor, (6) evaluation of labor market policies and projects and (7) general labor economics.

IZA Discussion Papers often represent preliminary work and are circulated to encourage discussion. Citation of such a paper should account for its provisional character. A revised version may be available on the IZA website (www.iza.org) or directly from the author. 


\section{ABSTRACT}

\section{Entrepreneurial Ventures and Wage Differentials Between Germans and Immigrants*}

This paper focuses on the entrepreneurial undertaking of immigrants and natives in Germany. We first study factors that affect the sorting of individuals into self-employment and then we investigate whether self-employment has a differential effect on the wages of individual workers and can lead them to economic success. We employ recent data from the German Socioeconomic Panel that allow us to identify and compare four distinct groups: West Germans, East Germans, guestworkers, and ethnic Germans. We find that the probability of self-employment increases significantly with age for all groups. For immigrants, the years-since-migration exhibits a U-shape. During the first years since migration the likelihood of self-employment decreases over time. However, when immigrants have accumulated more years of residence in Germany, the likelihood is increasing again. This suggests that once immigrants have overcome the initial adjustment shock, self-employment is a means to take advantage of the opportunities of the host country and achieve a higher socio-economic standing. Among immigrants, guestworkers are twice as likely to choose selfemployment as ethnic Germans. Further, we find that self-employment is a lucrative choice only for Germans who are in the upper end of the income distribution. "Rich" self-employed Germans enjoy a wage premium compared to their salaried counterparts. However, immigrants are able to traverse the socioeconomic gap through self-employment, irrespective of the part of the distribution they are at. Self-employed immigrants earn $22 \%$ more than the salaried immigrants.

JEL Classification: J23, M13, J24, J61, J31

Keywords: entrepreneurship, self-employment, occupational choice, immigrants, wage differentials

Corresponding author:

Amelie Constant

IZA

P.O. Box 7240

53072 Bonn

Germany

Tel.: +492283894301

Fax: +492283894180

Email: constant@iza.org

\footnotetext{
* This study has been made possible through various research visits to DIW Berlin and IZA in Bonn. We are grateful for the access to the data, and many useful comments and insights from Klaus $F$. Zimmermann. An earlier version of this paper was presented at the annual conference of the Academy of Entrepreneurial Finance in New York City, April 2002.
} 


\section{Introduction}

Entrepreneurship not only injects new dynamism into a country's economy but it is also of great importance for the economic prosperity and the future economic development of a country. Self-employment as an effective form of entrepreneurship creates new jobs and brings new products to the market; it is also a significant element in combating unemployment and welfare drain. Entrepreneurship encompasses a broad spectrum of types of activities, ranging from small "mom and pop" to hi-tech business and electronic commerce. It often starts as a small business and can turn into a successful company. Nevertheless, most new jobs emanate from small enterprises.

In the US, part of the American dream for natives and immigrants alike is to have "your own business." Whereas entrepreneurship flourishes in the US for any ethnic group, and whereas entrepreneurship is high in the European Union's employment strategy, entrepreneurial activities in Germany are comparatively very low. Surprisingly for the largest immigrant country in Europe, the share of self-employed immigrants in the German labor force is estimated to be around $8 \%$.

Recently, a burgeoning number of nascent enterprises ${ }^{1}$ show that there is a growing business culture in Germany, and they have attracted the government's attention to ensure their boost. A recent study by the Deutsche Ausgleichsbank-Gründungsmonitor 2002 on entrepreneurship activities of foreigners in Germany found, inter alia, that entrepreneurs of foreign origin employ, on average, employ more workers than Germans do (Lehnert 2003). The German government is now actively seeking to encourage, foster and strengthen the performance and competitiveness of small or mid-size enterprises (SMEs) and offers them new growth development possibilities.

Whereas self-employment is important for the well-being of the economy as a whole, it is more critical for the immigrant population, and is considered to be an essential factor in the immigrant adjustment process in the host country. The conjecture of the neoclassical human capital theory is that immigrants are a self-selected group of rational

\footnotetext{
${ }^{1}$ However, the percent of new enterprise formation as a percentage of total enterprises is $15.7 \%$ (annual average between 1995 and 2000).
} 
individuals who are willing to undertake risks in order to maximize their lifetime earnings and better their lives. They are characterized by a strong incentive to invest in human capital and have the inner drive to succeed in the host country's labor market. Immigrants have also the ability to respond to new opportunities and adjust in a new environment. By virtue of their willingness to assume the risk of migration (both pecuniary and psychic) and undertake this new and often risky venture they become the first entrepreneurs ${ }^{2}$. Put differently, immigrants as risk takers, are more dynamic and ambitious, can handle changes and are, thus, inherently more prone to becoming self-employed than any other group.

In economics, the prevailing framework is that of income choice (Lucas (1978)). Specifically, an individual chooses between self-employment or salaried work based on the monetary outcomes of that choice. The human capital paradigm implies that the best and the brightest will go into self-employment because if offers the opportunity for considerable economic success. However, besides the drive for financial rewards, individuals might choose self-employment as a corrective measure to job mismatch or as an option for independence and psychological boost of self-worth. For immigrants, in particular, it has been argued that impediments to good jobs and to upward occupational mobility as well as discrimination in the labor market may impel immigrants to undertake the selfemployment avenue. In fact, entrepreneurship may be the only avenue for their socioeconomic mobility (Light 1972). Self-employment is also a way out of discrimination in paid employment (Clark and Drinkwater 1998).

The prevalence of self-employment among both immigrants and natives in the labor market has been researched and documented by many studies in the US (Fairlie and Meyer, 2000, 1999; Lunn and Steen, 2000; Bates, 1997; Lofstrom 2002; Chiswick, 1978; Borjas and Bronars 1989; Yuengert 1995), in Canada (Li 2001), and in Europe (Blanchflower and Oswald 1998; Audretsch 2002). In general, self-employment is viewed as a positive choice and as a means to be creative and rewarded in the labor market. Not only selfemployed immigrants have higher annual incomes than salaried workers but they also have

\footnotetext{
${ }^{2}$ By definition, an entrepreneur is an individual who identifies opportunities, organizes, operates, and assumes the risks of a business venture.
} 
higher incomes than comparable self-employed natives, albeit there is substantive variance among the ethnic groups(Borjas 1986). The incidence of self-employment is higher for older workers and creates higher feelings of job satisfaction (Blanchflower et al. 2001).

However, immigrant entrepreneurship in Germany has been under-researched. Often the immigrant assimilation studies exclude the self-employed. The existing research on the self-employment of immigrants and natives in Germany (Wagner 1995; Wagner and Sternberg 2002; Audretsch and Fritz 2002) has left some questions unanswered. Germany is a highly industrialized country with a strong economy and a growing business sector that attracts a large number of immigrants and warrants further research.

This paper focuses on the entrepreneurial endeavors of immigrants and natives in Germany. We seek to answer the following research questions. First, who are the selfemployed, what are their characteristics, and what factors affect the sorting of individuals into self-employment? Second, does self-employment have a differential effect on the wages of individual workers and can it lead them to economic success. To answer these questions we analyze the economic and social determinants of the probability to become an entrepreneur and we estimate earnings regressions that gauge the assimilation effect. We control for the standard human capital variables and we augment the analysis to account for labor market characteristics, demographics, social, and psychological ties. For the empirical analyses we employ recent data from the German Socioeconomic Panel (GSOEP).

The rest of the paper is structured as follows: in Section 2 we delineate Germany's migration system and institutional settings with regards to the self-employed, which can elucidate our results. In Section 3 we present our methodological approach and outline the hypotheses of our study, in Section 4 we discuss the data set and present the characteristics of the populations under research, and in Section 5 we deliver and discuss the results of our analyses. We conclude in Section 6. 


\section{Immigration in Germany and Institutional Settings}

\subsection{Immigration Framework}

Since the late 1950's Germany has experienced massive migration comparable to the level of the First American Great Migration of the early 1900's. The immigrants of the 1950's, 1960 's, and 1970's, the guestworkers, ${ }^{3}$ were recruited by German employers to work in the German factories and relieve Germany from labor shortages. They came from Italy, Spain, Greece, Portugal, Yugoslavia, and Turkey according to bilateral treaties with the respective sending countries. ${ }^{4}$ Guestworkers were recruited on a short term temporary basis according to the 'rotationprinzip.' This phase lasted up until the halt of recruitment in 1973. After 1973, virtually all migration to Germany is due to family reunification with the exception of European Union members. The enlargement of the European Union in the 1980's and 1990's allowed all state members to legally live and work in Germany. Currently, this includes all guestworkers except Turks and ex-Yugoslavs.

The fall of the iron curtain in the 1990's, also prompted a plethora of immigrants in Germany. In reality, this migration has started in the late 1980's. Roughly 4 million immigrants settled in West Germany from 1988 to 1996 making this migration wave comparable to the mass migration of Jews from the ex-USSR to Israel. They are the "ethnic Germans," who according to the German constitution have the right to migrating to Germany. They are differentiated into the East Germans or Übersiedler and the East Europeans or Aussiedler. The other immigrants from East Europe mainly from Poland, Romania, and the former USSR, who have German origins are the Aussiedler. By the end of the millennium the immigrant population in Germany has risen to more than 10 percent, making Germany a de facto immigrant nation.

${ }^{3}$ The word guestworker is the literal translation of the German word "gastarbeiter" and reflects the notion these immigrants were invited to work in Germany, yet they were not expected to stay permanently.

${ }^{4}$ Treaties for recruitment were signed with Italy in 1955, Spain and Greece in 1960, Turkey in 1961, Portugal in 1964, and Yugoslavia in 1968. Agreements were also negotiated with Morocco in 1963 and Tunisia in 1965, but these nations never contributed many workers. 
We believe that the idiosyncrasies of the immigration and naturalization laws in Germany have shaped both the quantity (flow and stock) and quality (skills endowment) of German immigrants. The guestworkers, the majority of whom are Turks, remain a distinct group of legal immigrants, irrespective of whether they are born in Germany and/or are German citizens.

\subsection{Institutional Dimensions}

It is often argued that the higher rate of job creation in the US compared to that in Europe is likely linked to the relative ease of new entry and expansion by entrepreneurial firms (Krueger and Pischke 1997). Entrepreneurs can be encumbered or empowered by the institutional settings of a country. Credit market imperfections, labor market rigidities, legal structures, and administrative red tape are the obvious culprits. Germany is characterized by a restrictive financial system whereby banks represent the major financial intermediary supplying capital to firms. Germany's labor market structure, with respect to wage floors, union representation, and work characteristics is not very conducive to starting up a business. Moreover, Germany's high regulated system requires that most workers have a specific professional training (Ausbildung). This training is critical when it comes to found a business. For potential immigrant entrepreneurs, this can be a serious impediment because many immigrants leave school without acquiring this training.

It has been argued that the segmented and regulated structure of the German labor market does not only constrict access to self-employment but it impedes immigrant earnings assimilation (Constant 1998). Wage differentials between Germans and immigrants are affected by the segregation of the immigrants into the low wage sector of the economy. Immigration laws as well as industrial or social barriers prevent mobility across sectors.

In the 1960s and 1970s, because guestworkers migrated with a guaranteed paid employment there were hardly any immigrants in self-employment. With the exception of EU nationals and immigrants with a residence permit, the Foreigner's Law of 1965 explicitly prohibited immigrants to engage in business (Kanein 1988). However, the self-employment 
structure of the immigrants in Germany has changed appreciably since the 1970 s. ${ }^{5}$ Over the last decade, the absolute number of self-employed foreigners developed more dynamically than the number of self-employed Germans. The stock of self-employed foreigners rose by 23.6\% between 1992 and 2001, while the rise of self-employed was 17\% (Täubner 2003). Currently, immigrants from EU countries have the same legal rights as German entrepreneurs. Immigrants from non-EU countries are subject to the Foreigners Act (Ausländergesetz), which poses restrictions on the right to freely choose occupation, place of work etc. If they do not have an unlimited residence permit, which, among other things, is a direct function of time in Germany, they have to apply for a permission to found a business. In practice, however, the approval of such applications has been liberalized over the last years.

Nonetheless, immigrants face hurdles in their choice for self-employment such as the ability to raise or secure capital, to acquire managerial talents, and to capture market opportunities. One of the most important hurdles is credit constraint or financial capital for start-up business. The largest fraction of newly founded businesses in Germany is financed by the entrepreneur's own capital in combination with outside capital provided by credit institutes. Venture capital, private investors, or business angels continue to play a role in start-up financing. In the case of immigrants, family and friends are usually the business angels. Another hurdle is the lack of knowledge about the support programs that are available to encourage and promote self-employment, or about the existing consulting centers. However, even if immigrants are informed and encouraged to go into selfemployment, the next hurdle is to overcome regulations. Experts criticize that there are too many regulations that hinder entrepreneurial activities, and advocate against unreasonable paperwork. Further, the complicated German tax system can also deter many potential business founders. Over the recent years many changes were made regarding the tax laws, often making it impossible for businesses to overview the system. For small businesses, in particular, it is quite costly to keep up with the regulations.

Another impediment to self-employment is the German "welfare culture" whereby less

${ }^{5}$ In the early 1970 s only 40.000 immigrants were registered as self-employed, and their businesses were tied to restaurants or to cater to the needs of their compatriots. 
privileged workers need to be protected from unemployment and from precarious, risky employment. A last reason why the German labor market directive has focused and encouraged paid employment rather than self-employment is the labor unions.

The German government is now actively seeking to encourage, foster and strengthen the performance and competitiveness of SMEs and offer them new growth development possibilities. In June 2002, the German government started assisting the development of a private risk capital market in Germany by making available in considerable volumes venture capital for young technology companies above all via the VTC - Venture Capital for Small Technology Companies. At the same time, with a revised mandate of the "bridging allowance"scheme (Uberbruckungsgeld) ${ }^{6}$ the German government tries to encourage the unemployed and disadvantage workers to pursue the self-employment avenue. Chancellor Schroeder, himself, pledged his support to unfettered jobs market, and his opposition to the German "welfare culture."

\section{Modeling, Hypotheses, and Variables}

\subsection{Methodology}

Empirically, the unit of the analysis is the individual. In the first part of the econometric analysis we model the choice behavior of workers as a binomial logit. We assume that individual agents in the host country are facing two alternatives: the option of becoming selfemployed versus the option of being a wage earner worker. Individual agents maximize utility gained from the attributes of that choice. Such behavior is described in probabilistic terms. We estimate the probability of becoming self-employed based on values of a set of explanatory variables. This probability is not directly observed. Logistic regression model is an advantageous technique for estimating models with a binary dependent variable. Our dependent variable $Y$ is a categorical variable that takes the value of one if an individual is self-employed and the value of zero otherwise.

\footnotetext{
${ }^{6}$ To be eligible, one must have received unemployment benefit or unemployment assistance for at least four weeks prior to taking up self-employment
} 
The choice probability, assuming a logistic distribution, is:

$$
P(Y=1 \mid X)=\frac{e^{\beta^{\prime} x_{i}}}{1+e^{\beta^{\prime} x_{i}}}=\Lambda\left(\beta^{\prime} x\right)
$$

where $I$ indexes the individuals. The parameters $\beta$ reflect the impact of changes in $X$ on the probability that $Y=1 .^{7}$ The virtue of equation (1) is that its inverse (the log odds ratio ${ }^{8}$ ) has the following closed form:

$$
\ln \left(\frac{P}{1-P}\right)=\beta^{\prime} x
$$

The explanatory variables in $X$ consist of a set of human capital variables, individual specific characteristics, socioeconomic characteristics, dummies indicating the country of origin group (guestworker, or other immigrant), psychological attachments to Germany, as well as attitudinal variables. For the immigrant group we include additional explanatory variables, such as pre-migration schooling, and the number of years the immigrant has accumulated in Germany. All these independent variables are expected to affect the individual's probability to become an entrepreneur. The model is solved with maximum likelihood estimation. Since likelihood equations are non-linear in the parameters $\beta$ an iterative algorithm is used for the maximization of the likelihood function. The resulting estimates, b, are asymptotically unbiased, consistent, normal, and efficient.

Finally, the following equation

$$
P(Y=1)=\frac{1}{1+e^{-b^{\prime} x}}
$$

${ }^{7}$ The parameters of the logit are not necessarily the marginal effects, but vary with the values of $x$ as: $\theta E[y] / \theta x=\Lambda(\beta x)[1-\Lambda(\beta x)] \beta$ or $\theta E[y] / \theta x=P(Y=1)[1-P(Y=1)] \beta$. This is why the odds ratio is used. In essence, the estimated coefficient $b$ represents the change in log odds for a unit increase in the independent variable.

${ }^{8}$ The odds are the ratio of two probabilities for any mutually exclusive events or $\mathrm{P} /(1-\mathrm{P})$ 
gives the predicted probabilities of self-employment for the representative individual in each ethnic group. The actual probabilities can be evaluated either at the sample means of the $X_{\mathrm{s}}$ or at specific values of the $X_{\mathrm{s}}$. The results from this exercise will give us insights into the selfselection process and the role of the different characteristics of choosing the entrepreneurial avenue. We expect that the more talented individuals, who are better educated, have good health and more years of residence in Germany will have a higher probability of becoming entrepreneurs.

Next, we operationalize the earnings assimilation of entrepreneurs in Germany. The underlying assimilation assumption is to compare the earnings of the self-employed to those who are salaried workers. Put differently, our question here is: controlling for individual and labor market characteristics, does self-employment status have an independent effect on wages? The estimation of earnings is given by the following structural equation (Mincerian wage equation):

$$
\ln W_{j}=X_{2 j}^{\prime} \beta_{2}+Y S M_{j}^{\prime} Y_{2}+\epsilon_{j}
$$

with $j$ denoting the number of observations. The dependent variable is the natural logarithm of gross weekly earnings, and $X$ is a vector of socioeconomic characteristics similar to those specified in the logistic analysis but fine tuned to identify earnings. For example, here we include labor market characteristics and labor market structures. The vector YSM stands for years of residence one has accumulated in Germany, the chief variable in the assimilation estimation for immigrants. We include the square of YSM to capture any diminishing returns on earnings. The YSM coefficients in $\mathrm{Y}_{2}$ along with the estimates of the coefficients in Age measure the pure assimilation effect. Lastly, $\epsilon_{\mathrm{j}}$ is the stochastic error assumed to be independent of the $X_{s}$. Following the premises of the neoclassical human capital theory, we expect that the healthier and better educated individuals will have higher earnings. Similarly, we expect the earnings profiles with respect to age and YSM to have an inverted U-shape. If self-employed workers, are positively self-selected for their inner drive to be independently successful and to climb the socioeconomic ladder, they should also earn significantly higher wages, all else equal. Both the logit and wage regressions are estimated on three groups of men in Germany. Namely, the West Germans, the East Germans, and the immigrants - both 
the guestworkers and the new immigrants. We believe that each group is cohesive and homogeneous and is governed by similar experiences. Yet, there are socio-economic and labor market differences among groups that warrant separate analyses.

\subsection{Variables and Hypotheses}

The explanatory variables used in this paper include human capital variables (schooling in Germany, schooling in the home country, health status, and YSM), and labor market variables (hours working per week, tenure/seniority with job, public/private sector, and occupational prestige scores). We also included variables that show socioeconomic and psychological attachments to Germany (own a dwelling in Germany, desire to stay in Germany, and feelings of belonging), and other attitudinal (financial worries) and control variables (marriage). For immigrants we measure the effects of years of schooling and vocational training in the home country and years of schooling and vocational training in Germany separately. That way we control for differences in the initial stock of human capital (education before migration) and render immigrants' education in Germany qualitatively similar to that of Germans and among themselves.

The age variable shows that older individuals are more likely to choose selfemployment, albeit at a discounting rate. Older workers have already experience in the labor market, have more acquaintances, a larger social circle, and know what they want. They may also have accumulated more initial capital through savings and can finance their own business. For immigrants, the YSM variable measures the time and quality of exposure to the German environment. It measures labor market experience and human capital accumulated in Germany, including linguistic integration. It also measures the familiarity of immigrants with the laws and the institutions, and their easiness in understanding and processing the stimuli of the new country, and their understanding of intercultural dynamics. For those immigrants with missing values in the YSM variable, we carefully calculated the YSM variable following a simple algorithm: if the individual is born in Germany then YSM equals the age of the individual. If the individual is born elsewhere but went to school in Germany we assigned years of migration according to whether the individual went to 
elementary or secondary school in Germany.

Marital status and young children in the household are additional determinants of selfemployment since they directly affect the tastes of the individuals. In principle, men who are married and have children will increase their work efforts and choose a job that can increase their chances to stand up tp family obligations. Attracted by the higher financial rewards of entrepreneurship married men who have children may choose self-employment because they feel responsible for providing for their family. Indeed, previous research has shown that "for men, self-employment is more of an avenue for career success, free from organizational constraints" (Hundley 2000, p. 103). Further, it might also be that men choose selfemployment because they count on the support of their wives and children, especially when they run certain types of small scale businesses. Wives (and children, especially in immigrant families) can either assist their husbands with the business or they can have a salaried job that can supplement the husbands' income during rough times.

Individuals who own their house will have a higher probability to choose selfemployment. This variable indicates the presence of extra assets required to open a business (like using the house as collateral for a loan). On the other hand, if higher earnings are what self-employed men are after, men who declared having financial worries will have a higher probability to become self-employed thinking that their financial problems will be solved. For immigrants, in particular, we include feelings of not belonging in Germany and desire to stay in Germany for a long time. Both variables should increase the probabilities to choose self-employment. The former will indicate that self-employment is the default option of "making it" in a country where they feel discriminated against, and the latter will indicate that the only way to be able to "make it" if they want to stay in Germany is through selfemployment.

We finally expect to find differences by ethnic groups. Among Germans, we expect the East Germans who have been raised in socialist economies to have a lower probability of becoming entrepreneurs. Similarly, ethnic Germans should also have lower probabilities for self-employment. Following previous results in the literature, we expect immigrants to have a higher probability of becoming entrepreneurs. In the analysis of the earnings, we expect individuals who have a higher occupational prestige score, work longer hours per 
week, and have longer tenure in their job to have higher earnings. We also conjecture that self-employed workers earn significantly more than their salaried counterparts.

\section{Dataset and Sample Characteristics}

\subsection{Dataset}

For the empirical analysis our data are drawn from the German Socioeconomic Panel (GSOEP), a nationally representative data set that has been conducted annually since 1984 . The GSOEP is administered by the German Institute for Economic Research (DIW) in Berlin, and is largely patterned after the US Panel Study of Income Dynamics. It started in 1984 in the former Federal Republic of Germany (FRG) with a sample of about 12000 respondents, 3000 of whom were legal immigrants. The latter are the guestworkers denoting a subset of immigrants whose head of the household originates from Italy, Greece, Spain, Yugoslavia, and Turkey. In 1984 guestworkers accounted for $75 \%$ of the foreign population living in Germany. In this ongoing project all individuals aged 16 or older are interviewed annually. Respondents are selected by a random walk procedure. The GSOEP contains rich socioeconomic information on both native Germans and legal immigrants. An important feature of the GSOEP is that it allows for separate analyses of Germany's guestworkers. The survey provides excellent information on the immigrants' pre-immigration profiles and the level of their socio-political integration in Germany (Soep 2001).

Since the reunification of the two Germanies in 1990, the GSOEP includes all German inhabitants from the West (FRG) and the East (GDR). In 1996 the immigrant data base was expanded to include the Übersiedler and the Aussiedler, they are the ethnic German immigrants from the former GDR and the repatriates from eastern Europe, namely Polish, Romanians, and ex-USSR, respectively. In 1998 the GSOEP was yet augmented by a refreshment sample of about 2000 individuals, both Germans and immigrants. Lastly, the innovation sample of 2000 added over 10000 individuals to the GSOEP. About $90 \%$ of these individuals are German citizens born in Germany. This innovation sample includes the Übersiedler, the Aussiedler, and the guestworkers. 
The GSOEP of the year 2000 is unique in that it includes all populations living in Germany in the beginning of the new millennium, namely native Germans, ethnic Germans, 'new' immigrants, and oversamples the 'old' immigrants or guestworkers. It also includes a lot of questions on the labor force participation, self employment categories, various aspects of life in Germany, and contains an assortment of attitudinal questions. More importantly, the 2000 data permit a more detailed analysis of the self-employed. We can, thus, differentiate between those self-employed in agriculture, in the free-lance or professional sector, and in other self-employed categories including working for a family business. Further, 200 was a good year for the German economy.

For the purposes of our analysis we carefully selected three samples out of the GSOEP 2000. Our idea is to make the samples as comparable as possible. We, therefore, selected the West German sample who reside in the former FRG, the East German sample, who mostly reside in the former GDR, and the immigrant sample. The latter consists of both the traditional immigrants in the former FRG, the guestworkers, and the "new" immigrants who come from the former eastern block countries, and, for the most part, reside in west Germany. The samples we selected for our analyses exclude those individuals who are enrolled in school, and those in the military, because military personnel follow different trajectories and may skew our estimates. Additionally, we restrict our analysis to individuals aged 18 to 64 who had no missing values in the variables employed.

Unfortunately, the small size of the sample on German and immigrant women could not justify a separate analysis, and thus, our analysis focuses on the self-employment of men in Germany in 2000. According to the selection criteria outlined previously, we ended up with 2039 West German men, 1375 East German men, 840 guestworker men, and 396 other immigrant men.

\subsection{Sample Characteristics}

Table 1 presents selected labor market and human capital characteristics of the 4 samples considered in our analyses. With regards to labor market characteristics, West Germans earn, on average, the highest wages among all groups. While East Germans earn 
the lowest wages this does not necessarily reflect any poor performance in the labor market but this is due to their geographic location. It appears that even 10 years after the reunification the former East Germany has not caught up to the western standards (Bauer and Zimmermann 1997). In fact, when we omitted the $8 \%$ of East Germans who live in the west the mean weekly wages decreased even more to 923DM (see Table A2 in Appendix). Among immigrants, the "new/ethnic" immigrants earn more than the guestworkers, who perform the poorest in West Germany. East Germans work the longest hours among all groups and guestworkers work the shortest hours among all groups. West German men stand out by their highest Treiman occupational prestige score, followed by East Germans and ethnic immigrants; guestworkers have the lowest occupational prestige score.

The majority of men across all samples work full-time. Once again, the big contrast is between West German men and guestworker men. East German men have the highest percentage of being registered as unemployed (13\%), followed by the immigrants. In sharp contrast with only $5 \%$ of West German men are registered as unemployed. West German men also are distinguished by being mostly in the white collar occupations (44\%), and by having the lowest percentage of blue collar jobs $(28 \%)$ among all samples. With regards to self-employment, we are very surprised to find such low percentage rates for all groups. West Germans men have the highest percentage $(10 \%)$ of self-employment, followed by East Germans with $7 \%$, guestworkers with $6 \%$, and by the "other/ethnic" immigrants with a low $4 \%$. Understandably, a higher percentage of Germans than immigrants has public sector jobs.

Men in all four groups are about 40 years old and the small differences in age are not significant. On average, both West and East Germans are the best educated having finished at least highschool. Among immigrants, guestworkers have less education than the ethnic immigrants, and only $25 \%$ of them declared speaking German. Noticeably, the preponderance of guestworkers is married. Across all samples, a substantial proportion of immigrants have children. With respect to wealth and economic independence, more than half of the West German men own their house, followed by an impressive $44 \%$ of East German men. Given that East Germans were under the socialist regime until ten years ago this is a high number for real estate ownership. A quarter of guestworker men also own their 
house in Germany, as is a surprising $27 \%$ of the ethnic immigrants who own their house in Germany. Finally, this table shows that guestworkers have been living in Germany for about 27 years, indicating a rather permanent migration.

In Table 2, we portray the citizenship versus national identity issues. This Table clearly shows the purity of the German population. Both West and East Germans are 100\% German citizens and have been born in the German territory. With regards to the immigrant population in Germany, the GSOEP gives us the opportunity to look at their citizenship, their multiple nationalities, and the country they are born in. The summary statistics on the citizenship, nationality, and feeling of belonging on guestworkers and the other ethnic immigrants show quite a different picture. Guestworkers, who have been in Germany for 27 years are not politically integrated in Germany. Only about $24 \%$ of guestworkers are German citizens. Among the non-citizens, although $21 \%$ are born in Germany they have their parents' nationality: the majority are Turks and ex-Yugoslavs. ${ }^{9}$ About $13 \%$ of the non-citizen guestworkers said that they have applied for German citizenship. When these same individuals were asked if they would apply for German citizenship, could they keep their own an impressive $29 \%$ said yes.

Among guestworkers, $37 \%$ of them said that they feel as if they do not belong in any country. They live in Germany, yet Germany is not "home" for them. When they go back to their native country they feel that they do not belong there either. This is a high percentage of alienated immigrants. Evidently, long years of residence in Germany are not a sufficient condition for the guestworkers to feel that they belong in Germany. In contrast, only $19 \%$ of the ethnic immigrants feel alienated, and they have been in Germany for a much shorter period. Guestworkers also express the most worries about their financial situation. For example, $26 \%$ of guestworkers worry about their finances as opposed to $13 \%$ of West Germans. A quarter of the other ethnic immigrants also worry about finances, followed by

${ }^{9}$ Up until recently citizenship in Germany was synonymous to nationality and was based on the "law of blood." Accordingly, individuals born outside Germany are Germans if their ancestry is German. The new law combines the existing law of blood with the "law of soil" that is the law in the US, for example. Individuals born in Germany are Germans but they have to decide by the age of 18 which nationality to keep. Naturalization rates increased by $130 \%$ in 2000 mainly due to the decreased time limit. 
$23 \%$ of East Germans.

Following the same disaggregation of the samples, Tables 3 and 4 present selected characteristics on the self-employed and the salaried men respectively. The self-employed samples are reduced to 202 West Germans, 100 East Germans, and 64 immigrants. Comparing Table 3 to Table 1, and to Table 4, we see that the self-employed are a selected group of exceptional individuals who are "better" than the wage earners and the entire population in many respects. Overall, across all groups, self-employed men work more hours per week, earn more money, have higher Treiman prestige scores, more education, and better health than their salaried counterparts. They are also a little older, and a much higher percentage of them own their houses. With the exception of the ethnic immigrants, a higher percentage of self-employed men are married and have young children in the household.

Comparing immigrants to Germans, Table 3 shows that self-employed immigrants, although much younger than West German men, can reach economic parity with West German men. For guestworkers specifically, Table 3 documents a positive selection with respect to wages, human capital, and demographics. Compared to their wage/salary counterparts in Table 4, self-employed guestworker men have higher wages, more education, better health, and more of them speak German. Self-employed guestworkers also have a remarkably high Treiman prestige score, compared to salaried guestworkers, indicating that self-employment is a vehicle for higher socioeconomic status. Moreover, a higher percentage of the self-employed guestworkers is married and has young children in the house, and a higher percentage owns their house than salaried guestworkers. Noticeably, self-employed guestworkers have a higher percentage of citizenship than the salaried guestworkers by $44 \%$. However, the years of residence in Germany, are almost the same for self-employed, salaried workers, and all guestworker men. Overall, these summary statistics show that self-employed immigrants can traverse the socio-economic gap and climb high on the socio-economic ladder.

Table A1 in the Appendix shows the types of self-employment our samples are in. Overall, the majority of self-employed men own small-scale businesses with 9 or less employees. More West Germans than any other group are in the self-employed farmer category. The vast majority of self-employed men across all groups lies in the "other 
business" category employing less than 9 workers. This category spans from retail shops, to restaurants, tourist offices, home caring, construction business, etc. Guestworkers have the largest share in this category (84\%). The large variance in the free-lance professional category across groups is of interest. This category includes the "independent professions" (such as lawyers and doctors), artists, consultants, etc. An impressive 31\% of the other immigrants or ethnic Germans are in the free-lance professional category followed by $24 \%$ of West German men, and a low $15 \%$ of East German men. Only $8 \%$ of guestworker men are in the free-lance professional business category. On the other hand, more guestworkers than any other group help in the family business. This indicates that guestworkers rely more on kinship and familial support when they open a new business.

\section{Estimation Results}

\subsection{Binomial Logit Results}

In Table 5 we present the results of the binomial logit on the probability of selfemployment for the respective samples. In this exercise we estimated logits for West Germans, East Germans, and Immigrants separately. Due to the small number of observations for guestworker and ethnic immigrants we combined the two immigrant groups in one sample and created a dummy variable to capture the guestworker versus ethnic immigrant status. For each group, we present the coefficient estimates with the standard errors in parenthesis underneath; the asterisk denotes the significance level. In the adjacent column we present the odds ratios.

Across all groups, the odds of becoming self-employed increases significantly with age at a decreasing rate. As predicted, and in line with other studies (Blanchflower et al. 2001), this indicates that self-employment is an effective choice later in life. For West Germans, disability exhibits a negative link to the odds of choosing self-employment. Surprisingly, we find that marriage is a deterrent to entrepreneurship for West German men. All else equal, married West German men are more likely to choose salaried work by $52 \%$. This is in odds with the conjecture that women subsidize their husbands' jobs. That is, men 
rely on their wives for a steady income if they work outside of the family business and count on their helping directly in the business. One explanation for this finding is that the German family is more traditional and conforms to the "breadwinner" ideology. That is, men work to provide for their family and women take care of the children and the household. This division of labor combined with the fact that self-employment is a more precarious source of income and that it is more time intensive, would not be an optimal choice for West German men.

However, when German men have young kids they are more likely to choose selfemployment by $60 \%$. One explanation for this puzzling finding comes from Table A1 in the Appendix. We suspect that the presence of children makes individuals think differently depending on the type of business they are in. There are two different forces acting together in the logit regression, capturing different motives for being self-employed. At the lower end of the self-employment - farming, other business, and help with family business - the presence of children is a positive determinant because children can help with the business. This effect dominates since the majority of West German men are in small scale farming and other business types. However, this rational does not apply to the upper professions.

The other curious result for West German men is that education is not a significant determinant of self-employment propensity. We suspect that this could be due to the little variation in the education variable. The rest of the results are as expected. West Germans who are home-owners, and have financial worries are significantly more likely to choose selfemployment. In fact, financial worries almost double the probability of self-employment for West German men.

In contrast to West German men, education has a strong differential effect on the probability to choose self-employment for East German men. In fact, additional years of schooling increase the odds of self-employment by $11.5 \%$. This suggests that higher education is not rewarded enough in the salaried sector in East Germany and more educated workers choose self-employment as an alternative to higher returns to schooling. Home-owners are again, more likely to choose self-employment than renters.

For immigrant men, the odds of becoming self-employed double for guestworkers as opposed to the other immigrants. Self-employment probabilities decrease at an increasing rate by YSM. This U-shape finding means that when immigrants first arrive to Germany or 
soon after their arrival, they have a lower probability to choose self-employment probably because of institutional barriers and liquidity constraints. However, the longer the immigrants stay in Germany, the probability to choose self-employment becomes positive. Selfemployment for immigrants is rather a choice against structural barriers, limited employment choices, and discrimination in the labor market. Immigrants often experience social exclusion, and entrepreneurship maybe a way of cutting through it and being accepted. Lastly, none of the rest of the variables are significant determinants of self-employment for immigrant men. Comparing immigrants to Germans, differences emerge in the health, marital and wealth status. While these factors have a strong differential impact upon the odds of choosing selfemployment for Germans (especially West Germans), they have an insignificant impact for immigrants.

\subsection{Earnings Regression Results}

In Table 6 we present the results of the human capital earnings regression for the respective samples. In this exercise we study the effect of self-employment on the earnings based on the sample of workers who have reported positive wages. We estimate log weekly wage regressions for West Germans, East Germans, and immigrants separately. Due to the small number of observations for guestworker and ethnic immigrants we combine the two in one sample and create a dummy variable to capture their different immigrant status. For each group we present the coefficient estimates with the standard errors in parenthesis underneath. The asterisk denotes the significance level. For the wage regressions the respective samples were reduced to 1550 West German men, 961 East German men, and 882 immigrant men.

For the German samples we disaggregated by "high" and "low" wages or by "rich" and "poor" workers. Our reasoning is that the "poor" workers have completely different behavior in the labor market and may skew our results with regards to self employment. In a way, this is equivalent to distinguishing low level self-employment jobs from upper class entrepreneurship. Specifically, for West German men, we categorized as "rich" those who earn more than 1000DM per week and as "poor" those who earn less than or equal to 
1000DM per week. We then ran regressions for the "rich" and the "poor" separately. For the East Germans, the cut-off point for "rich" and "poor" is at 800DM per week because wages in East Germany are lower than in the west. This dichotomy in the labor market does not apply to immigrants. In general, immigrants operate in the same segment of the market. For immigrant men, therefore, we did not disaggregate by wages. The guiding behavior of immigrant workers is not whether they are rich or poor but whether they are immigrants or not. As Figure 1 illustrates, the wage distribution differs for Germans and immigrants. For example, immigrants are not represented in the upper end of the distribution but are clamped together in the low and average segment of the distribution.

As expected, we find that the age-earnings profile is concave for all samples. That is, earnings increase with age at a decreasing rate. From the coefficients on the selfemployment dummy we see that self-employment status has a significantly differential effect on the earnings of men in Germany. However, the direction of the effect differs across samples. For both the West and East German samples, we find that the "rich" self-employed Germans are better off being self-employed, but, the "poor" self-employed Germans are better off being salaried workers. Put differently, our results show that the labor market in Germany does not give equal chances to the self-employed workers across the wage distribution. Clearly, for the Germans, those who are at the lower end of the wage distribution earn lower wages if they are self-employed ( $54 \%$ less than the salaried workers). In sharp contrast, those who are at the upper end of the wage distribution earn about $15 \%$ higher wages if they are self -employed than if they are salaried workers. One explanation for this finding is that the Germans who are at the low end of the wage distribution may have other attractive job alternatives; like finding a good job with the government, or some kind of salaried work that pays more that self-employment. At the upper end, however, selfemployment offers options that are not available in the public or private sector and the men who choose self-employment are rewarded for it.

For immigrants, being self employed increases their earnings by $22 \%$ compared to their salaried counterparts. Clearly, immigrants in Germany operate under different structures in the labor market than Germans. Whether "poor" or "rich," the alternative of being salaried workers does not pay well for immigrants in Germany. In fact, we believe that this is even 
more accentuated at the lower end of the distribution. For example, the flower stand immigrant vendor cannot find a good salaried job with his education, age, YSM, etc. But selfemployment is a viable working alternative.

Table 6 also shows that earnings increase for hard working individuals who work more hours per week, across all samples. It is noteworthy, that longer hours of work are rewarded more for the "poor" Germans and the immigrants. With respect to the rest of the predictors, we find that they differ on their sign and significance level across the samples. For West Germans, education is rewarded in the labor market whether they are "poor" or "rich." However, education is rewarded only for the "rich" East Germans and has no significant effect on the earnings of the "poor" East Germans or the immigrants. Indeed, for immigrants, neither pre- or post migration schooling is a significant determinant of earnings. We, further, find that disabled workers are penalized in the labor market but this is only significant for the "poor" West Germans and the immigrants. Our results are consistent with previous analyses in Germany showing a duality in the labor market and the struggle for assimilation for the immigrant population (Constant 1998).

As expected, we find that high Treiman occupational scores increase wages but only for the "rich" Germans and the immigrants. The long tenure with a firm or seniority is significant and positive for the "poor" West Germans, the "rich" East Germans, and the immigrants. This reiterates the different structures in the labor market in Germany. Those West Germans who work in public sector earn $12 \%$ less than those in the private sector. Lastly, marriage is beneficial only for the "rich" West German men, offering them a marriage premium in the labor market. For the immigrant sample specifically, we find that years-sincemigration is not a significant determinant of their earnings. This finding is in line with other studies on immigrant assimilation in Germany, and shows that there is no significant improvement on the wages of immigrants with additional time in Germany. Overall, in this study we are able to confirm Borjas' thesis that self-employed workers earn more than salaried workers, and that self-employed immigrant workers earn more than comparable selfemployed natives. 


\section{Conclusion}

In this paper we analyzed the entrepreneurial behavior and monetary success of three distinct populations in Germany in 2000. Based on the GSOEP we estimated the probability to choose self-employment for West German men, East German men, and immigrant men (both guestworkers and new/ethnic immigrants). We, further, studied the issue of selfemployment status in the labor market, and estimated earnings regressions to see whether self-employment has a differential effect on the wages of individual workers. The empirical results presented in this paper suggest that, compared to salaried workers, the workers who choose self-employment have distinct characteristics and self-employed workers are faring better in the labor market.

Overall, we found that the probability of self-employment increases with age at a decreasing rate. Education propels self-employment choices for East Germans only. For immigrants, the years-since-migration exhibits a U-shape. During the first years since migration, immigrants choose self-employment as a channel for entry into the labor market of the host country, while the likelihood decreases over time. However, when they have accumulated more years of residence in Germany, the likelihood is increasing again. This suggests that once immigrants have overcome the initial adjustment shock, they see selfemployment as a means to take advantage of the opportunities of the host country and achieve a higher socio-economic standing. Among all immigrants, we find that, all else equal, the odds of becoming self-employed double for the guestworkers. Among Germans, homeowners are more likely to choose self-employment.

Whereas from the summary statistics self-employment appears to be a lucrative choice for all groups, controlling for individual and labor market characteristics, this is only true for Germans who are at the upper end of the income distribution and for immigrants. Self-employed Germans - both West and East - in the upper end as well as immigrants from any part of the distribution enjoy a wage premium compared to their salaried counterparts. Immigrants, specifically, are able to traverse the socioeconomic gap through selfemployment. That is, not only they earn more than the salaried immigrants but they enjoy a higher occupational prestige as well. It is noteworthy that self-employment is detrimental for 
the earnings of those Germans who are in the lower end of the distribution. The intrinsic precariousness, and the often long hours of work that characterize the self-employment sector might deter poor Germans from going into self-employment because they have other options.

In sum, the self-employed sector in Germany is at the very early stages of development but has the potential to grow. For the sake of the growth of entrepreneurship in Germany is it imperative that individuals have unfettered access to the formal labor markets. Especially for immigrants, it is important that they be given the opportunities to implement their entrepreneurial endeavors and contribute to the growth of the German economy. 


\section{References}

Aronson, R.L., 1991. Self-employment: A labor market perspective. ILR Press, Ithaca, NY. Audretsch, D.B., 2002. Entrepreneurship: A survey of the literature, paper prepared for the European Commission, Enterprise Directorate General.

Audretsch, D.B., Fritsch, M., 2002. Growth regimes over time and space, Regional Studies 36, 113-124.

Bates, T., 1997. Race, self-employment, and upward mobility: An illusive American dream. Woodrow Wilson Center Press, Washington, D.C.

Bauer, T.K., Zimmermann, K.F., 1997. Unemployment and wages of ethnic Germans, Quarterly Review of Economics \& Finance 37, 361-377.

Baumol, W.J., 1990. Entrepreneurship: Productive, unproductive and destructive, Journal of Political Economy 98, 893-921.

Blanchflower, D.G., Oswald, A., Stutzer, A., 2001. Latent entrepreneurship across nations, European Economic Review 45, 680-691.

Blanchflower, D.G., Oswald, A., 1998. What makes an entrepreneur, Journal of Labor Economics 16, 26-60.

Borjas, G.J., 1994. Ethnicity, neighborhoods, and human capital externalities, National Bureau of Economic Research, Working Paper No. 4912.

Borjas, G.J., 1986. The self-employment experience of immigrants, Journal of Human Resources 21, 485-506.

Borjas, G.J., Bronars, S.G., 1989. Consumer discrimination and self-employment, Journal of Political Economy 97, 581-605.

Chiswick, B.R., 1999. Are immigrants favorably self-selected?, American Economic Review 89, 181-185.

Clark, K., Drinkwater, S., 1998. Ethnicity and self-employment in Britain, Oxford Bulletin of Economics and Statistics 60, 383-407.

Constant, A., 1998. The Earnings of Male and Female Guestworkers and Their Assimilation into the German Labor Market: A Panel Study 1984-1993. Ph.D. Dissertation, Vanderbilt University. 
Dutz, M.A., Ordover, J.A., Willig, R.D., 2000. Entrepreneurship, access policy, and economic development: Lessons from industrial organization, European Economic Review 44, 739-747.

Evans, D.S., Leighton, L.S.,1989. Some empirical aspects of entrepreneurship, American Economic Review 79, 519-535.

Evans, L.B., Siegfried, J.J., 1994. Empirical studies of entry and exit: A survey of the evidence, Review of Industrial Organization 9, 121-155.

Faini, R., Galli, G., Gennari, P., Rossi, F., 1997. An empirical puzzle: Falling migration and growing unemployment differentials among Italian regions, European Economic Review41, 571-579.

Fairlie, R.W., Meyer, B.D., 2003. The effect of immigration on native self-employment, Journal of Labor Economics 21, 619-650.

Fairlie, R.W., Meyer, B.D., 1996. Ethnic and racial self-employment differences and possible explanations, Journal of Human Resources 31, 757-93.

Fonseca, R., Lopez-Garcia, P., Pissarides, C.A., 2001. Entrepreneurship, start-up costs and employment, European Economic Review 45, 692-705.

Grabka, M.M., Schwarze, J., Wagner, G.G., 1999. How unification and immigration affected the German income distribution, European Economic Review 43, 867-878.

Hundley, G., 2000. Male/female earnings differences in self-employment: The effects of marriage, children, and the household division of labor, Industrial \& Labor Relations Review 54, 95-114.

Kanein, W., 1988. Ausländerrecht, Beck: München.

Krueger, A.B., Pischke, J.-S., 1997. Observations and conjectures on the US employment miracle. National Bureau of Economic Research, Working paper No. 6146.

Lecker, T., Shachmurove, Y., 2001. Have the Kibbutzim Helped to Narrow the Socioeconomic Gap in Israel? In: DellaPergola, S., Even, J. (Eds.) Jewish Population Studies Vol. 29, Jerusalem.

Lecker, T., Shachmurove, Y., 1999. Immigration and socioeconomic gaps: Theory and applications, Applied Economics 31, 539-549.

Lehnert, N., 2003. Existenzgründungen durch Migranten in Deutschland: Ergebnisse des DtA-Gründungsmonitors 2002, in: Deutsche Ausgleichsbank (Ed.) Wirtschaftsdynamik durch 
Existenzgründungen von Migranten. Bonn, pp. 39-54.

Li, P.S., 2001. Immigrants' propensity to self-employment: Evidence from Canada, International Migration Review 35, 1106-1128.

Light, I., 1972. Ethnic enterprise in America. University of California Press, Berkeley and Los Angeles.

Lofstrom, M., 2002. Labor market assimilation and the self-employment decision of immigrant entrepreneurs, Journal of Population Economics 15, 83-114.

Lucas, R.E., Jr., 1978. On the size distribution of business firms, Bell Journal of Economics 9, 508-523.

Lunn, J, Steen, T.P., August 2000. An investigation into the effects of ethnicity and immigration on self-employment, International Advances in Economic Research 6, 498-519. Maxim, P.S., 1992 Immigrants, visible minorities, and self-employment, Demography 29, 181-198.

Nickell, S.J., Nicolitsas, D., Dryden, N., 1997. What makes firms perform well?, European Economic Review 41, 783-796.

SOEP Group, 2001. The German Socio-Economic Panel (GSOEP) after more than 15 years - Overview, Quarterly Journal of Economic Research 70, 7-14.

Täubner, M., 2003. Förderung ausländischer Existenzgründer durch die Deutsche Ausgleichsbank, in: Deutsche Ausgleichsbank (Ed.) Wirtschaftsdynamik durch Existenzgründungen von Migranten. Bonn, pp. 7-33.

Wagner, J., Sternberg, R., 2002. Personal and regional determinants of entrepreneurial activities: Empirical evidence from the REM Germany, Institute for the Study of Labor, IZA Discussion Paper No. 624.

Wagner, J., 1995. Firm size and job creation in Germany, Small Business Economics 7, 469-474.

Yuengert, A.M., 1995. Testing hypotheses of immigrant self-employment, Journal of Human Resources 30, 194-204.

Zimmermann, K.F., 1996. European migration: Push and pull, International Regional Science Review 19, 95-128.

Zimmermann, K.F., 1995. Tackling the European migration problem, Journal of Economic Perspectives 9, 45-62. 


\section{TABLE 1. SELECTED LABOR MARKET AND HUMAN CAPITAL CHARACTERISTICS BY}

ETHNICITY: MEN IN GERMANY

\begin{tabular}{cccc} 
WEST & GUEST & EAST & OTHER \\
GERMANS & WORKERS & GERMANS & $\begin{array}{c}\text { ETHNIC } \\
\text { IMMIGRANTS }\end{array}$ \\
\hline
\end{tabular}

\begin{tabular}{|c|c|c|c|c|}
\hline Monthly wages (in DM) ${ }^{1}$ & $5794.30^{\mathrm{a}}$ & $4569.40^{a}$ & $3815.55^{a}$ & $4838.48^{a}$ \\
\hline Weekly wages (in DM) ${ }^{1}$ & $1448.58^{a}$ & $1142.35^{\mathrm{a}}$ & $953.89^{\mathrm{a}}$ & $1209.62^{\mathrm{a}}$ \\
\hline Average weekly hours of work ${ }^{1}$ & $43.53^{\mathrm{a}}$ & $41.89^{\mathrm{a}}$ & $45.20^{\mathrm{a}}$ & $43.61^{\mathrm{b}}$ \\
\hline Length of time with firm ${ }^{1}$ & $11.91^{\mathrm{a}}$ & $10.00^{\mathrm{a}}$ & $7.29^{\mathrm{a}}$ & $6.42^{\mathrm{a}}$ \\
\hline Treiman Occupational Prestige Score ${ }^{1}$ & $44.12^{\mathrm{a}}$ & $36.96^{\mathrm{a}}$ & $40.94^{a}$ & $39.03^{a}$ \\
\hline Full time (in \%) & 78 & 68 & 70 & 75 \\
\hline Part time (in \%) & 2 & 2 & 1 & 1 \\
\hline Registered as unemployed (in \%) & 5 & 11 & 13 & 11 \\
\hline not employed (in \%) & 13 & 15 & 12 & 11 \\
\hline Public sector (in \%) & 19 & 6 & 15 & 8 \\
\hline blue collar (in \%) & 28 & 51 & 38 & 53 \\
\hline self employed (in \%) & 10 & 6 & 7 & 4 \\
\hline white collar (in \%) & 44 & 15 & 26 & 20 \\
\hline Age in years & $42.17^{a}$ & $40.74^{\mathrm{a}}$ & $41.97^{\mathrm{b}}$ & $40.12^{\mathrm{a}}$ \\
\hline Years of schooling in Germany & $12.26^{\mathrm{b}}$ & $5.51^{\mathrm{a}}$ & $12.37^{\mathrm{b}}$ & $4.33^{\mathrm{a}}$ \\
\hline Years of schooling in Home Country & - & 4.24 & - & 7.74 \\
\hline Speak German all the time (in \%) & - & 25 & - & - \\
\hline Speak native language all the time $(\%)$ & - & 15 & - & - \\
\hline Married (in \%) & 65 & 73 & 64 & 72 \\
\hline Single (in \%) & 28 & 23 & 28 & 20 \\
\hline Children in Household $<16$ yrs old $(\%)$ & 36 & 44 & 35 & 49 \\
\hline Own dwelling in Germany (in \%) & 55 & 25 & 44 & 27 \\
\hline Reside in West German territory (in \%) & 99 & 100 & 8 & 98 \\
\hline disability limits work (in \%) & 13 & 14 & 13 & 13 \\
\hline Years-since-Migration & - & 27.42 & - & - \\
\hline Number of Observations & 2039 & 840 & 1375 & 396 \\
\hline $\begin{array}{l}{ }^{1} \text { Number of Observations on workers } \\
\text { with positive income }\end{array}$ & 1550 & 590 & 961 & 292 \\
\hline
\end{tabular}

Note: ${ }^{1}$ Average based on sample of workers with $>0$ incomes

Note: ${ }^{a}$ The analysis of independent-samples t-test revealed a significant difference between West Germans and the other samples

${ }^{b}$ The analysis of independent-samples t-test failed to reveal a significant difference between West Germans and the other samples

Source: Own calculations from GSOEP 2000 
TABLE 2. SELECTED CHARACTERISTICS ON CITIZENSHIP AND ATTITUDINAL VARIABLES BY ETHNICITY: MEN IN GERMANY

\begin{tabular}{|c|c|c|c|c|}
\hline & $\begin{array}{c}\text { WEST } \\
\text { GERMANS }\end{array}$ & $\begin{array}{c}\text { GUEST } \\
\text { WORKER }\end{array}$ & $\begin{array}{c}\text { EAST } \\
\text { GERMANS }\end{array}$ & $\begin{array}{c}\text { OTHER } \\
\text { ETHNIC } \\
\text { IMMIGRANTS } \\
\end{array}$ \\
\hline German Citizen (in \%) & 100 & 23.69 & 100 & 83.08 \\
\hline Born in Germany (in \%) ${ }^{1}$ & 100 & 46.23 & 100 & 44.07 \\
\hline Have $2^{\text {nd }}$ Nationality ${ }^{1}$ & - & 14.57 & - & 10.33 \\
\hline Not born in Germany ${ }^{1}$ & - & 53.77 & - & 55.93 \\
\hline Born in Turkey $(\%)^{2}$ & - & 7.48 & - & - \\
\hline Born in ex-Yugosla ${ }^{2}$ & - & 92.52 & - & 100 \\
\hline Was inGermanyin $84^{2}$ & - & 93.46 & - & 5.98 \\
\hline Not German Citizen (in \%) & - & 76.31 & - & 16.92 \\
\hline Born in Germany (in \%) $)^{3}$ & - & 21.18 & - & 5.97 \\
\hline Turkish Citizenship (in \%) ${ }^{3}$ & - & 39.47 & - & 46.26 \\
\hline Yugoslav Citizenship (in \%) $)^{3}$ & - & 60.53 & - & 53.73 \\
\hline ApplyforGermanCitizen'p(\%) ${ }^{3}$ & - & 12.64 & - & 16.42 \\
\hline “ can have dual Citizen' $p(\%)^{3}$ & - & 29.02 & - & 40.30 \\
\hline Feel do not Belong (in \%) & - & 37 & - & 19 \\
\hline Want to stay in Germany (in \%) & - & 48 & - & 53 \\
\hline Worries about finances (in \%) & 13 & 26 & 23 & 25 \\
\hline Worries about immigration to Germany & 35 & 19 & 39 & 21 \\
\hline Worries about hostilityagainstforeigners & 25 & 29 & 24 & 21 \\
\hline Number of Observations & 2039 & 840 & 1375 & 396 \\
\hline \multicolumn{5}{|l|}{ Note: ${ }^{1}$ Based on the German Citizens } \\
\hline \multicolumn{5}{|c|}{${ }^{2}$ Based on the German Citizens who are not born in Germany } \\
\hline${ }^{3}$ Based on the NON German Citizens & & & & \\
\hline
\end{tabular}




\begin{tabular}{|c|c|c|c|c|}
\hline & $\begin{array}{c}\text { WEST } \\
\text { GERMANS }\end{array}$ & $\begin{array}{c}\text { GUEST } \\
\text { WORKER }\end{array}$ & $\begin{array}{c}\text { EAST } \\
\text { GERMANS }\end{array}$ & $\begin{array}{c}\text { OTHER } \\
\text { ETHNIC } \\
\text { IMMIGRANTS }\end{array}$ \\
\hline Weekly wages (in DM) ${ }^{1}$ & $1890.48^{\mathrm{b}}$ & $1873.03^{b}$ & $1161.11^{\mathrm{a}}$ & $2380.31^{a}$ \\
\hline Average weekly hours of work ${ }^{1}$ & 51.24 & 50.15 & 52.06 & 54.79 \\
\hline TreimanOccupationalPrestigeScore ${ }^{1}$ & 46.86 & 41.61 & 44.32 & 46.88 \\
\hline Age in years & 43.63 & 40.42 & 42.82 & 44 \\
\hline $\begin{array}{l}\text { Years of schooling \& vocational } \\
\text { training in Germany }\end{array}$ & $12.61^{\mathrm{a}}$ & $6.53^{\mathrm{a}}$ & $13.18^{\mathrm{a}}$ & $4.06^{\mathrm{a}}$ \\
\hline $\begin{array}{l}\text { Years of schooling \& vocational } \\
\text { training before migration }\end{array}$ & - & $4.11^{\mathrm{a}}$ & - & $8.78^{\mathrm{a}}$ \\
\hline Speak German all the time (in \%) & - & 31 & - & - \\
\hline disability limits work (in \%) & 10 & 6 & 7 & 6 \\
\hline Years-since-Migration & - & 28.02 & - & - \\
\hline Married (in \%) & 67 & 77 & 76 & 69 \\
\hline Single (in \%) & 23 & 17 & 16 & 25 \\
\hline Children in $\mathrm{HH}<16$ yrs old (in \%) & 47 & 46 & 53 & 44 \\
\hline Own dwelling in Germany (in \%) & 65 & 33 & 64 & 38 \\
\hline German Citizen (in \%) & 100 & 33 & 100 & 75 \\
\hline $\mathrm{N}$ & 202 & 48 & 100 & 16 \\
\hline${ }^{1} \mathrm{~N}$ (workers with positive incomes) & 146 & 38 & 75 & 13 \\
\hline \multicolumn{5}{|c|}{ Note: ${ }^{1}$ Average based on sample of self-employed workers with $>0$ incomes } \\
\hline \multicolumn{5}{|c|}{$\begin{array}{l}\text { a The analysis of independent-samples t-test revealed a significant difference between West Germ ans and } \\
\text { the other samples }\end{array}$} \\
\hline \multicolumn{5}{|c|}{$\begin{array}{l}{ }^{b} \text { The analysis of independent-samples t-test failed to reveal a significant difference between West Germans } \\
\text { and the other samples }\end{array}$} \\
\hline
\end{tabular}

Source: Own calculations from GSOEP 2000 


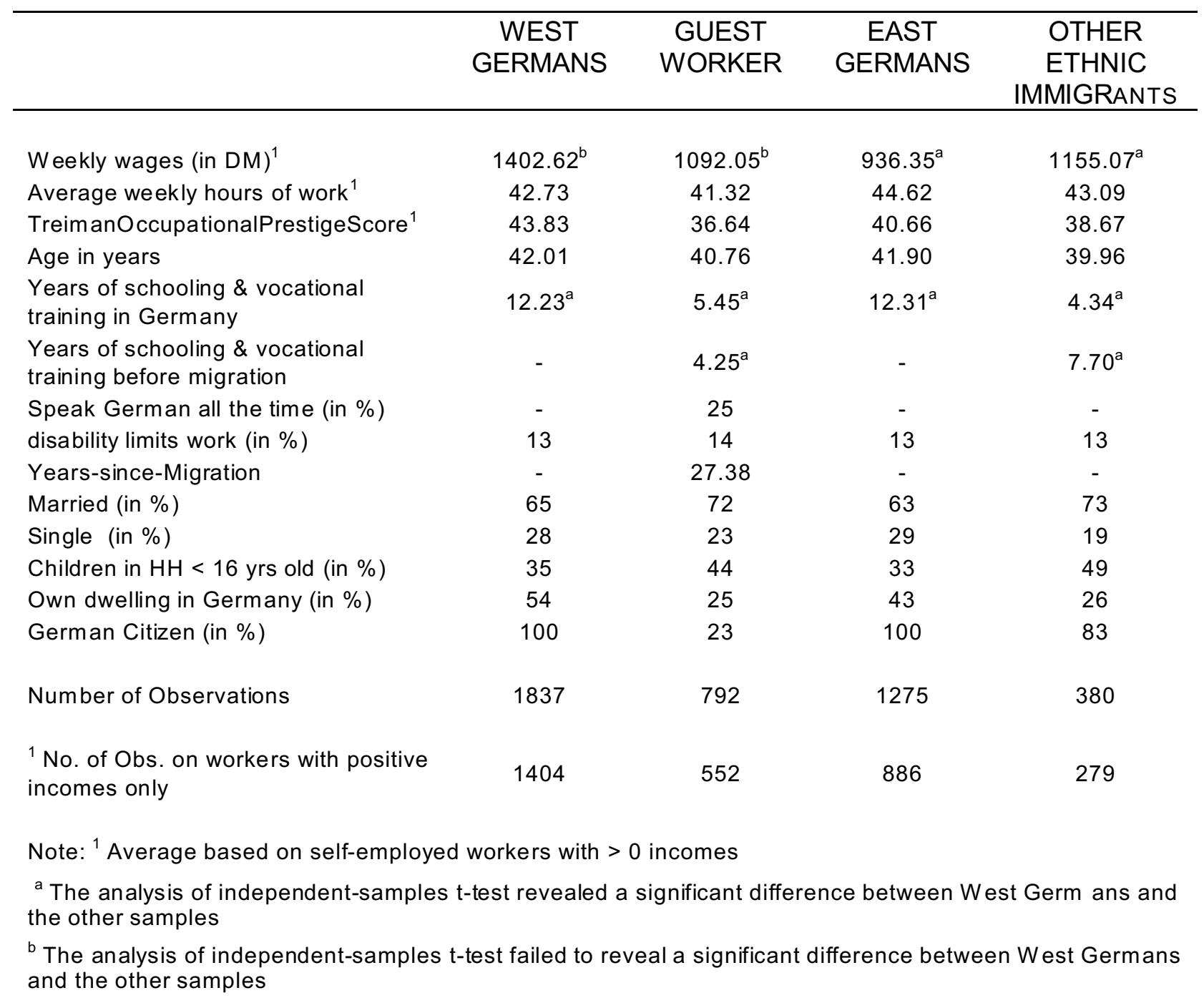

Source: Own calculations from GSOEP 2000 
TABLE 5. ESTIMATION RESULTS ON THE PROBABILITY OF SELF-EMPLOYMENT: MEN IN GERMANY IN 2000 (LOGITS)

\begin{tabular}{|c|c|c|c|c|c|c|}
\hline & \multicolumn{2}{|c|}{ WEST GERMANS } & \multicolumn{2}{|c|}{ EAST GERMANS } & \multicolumn{2}{|c|}{ ALL IMMIGRANTS } \\
\hline Parameters & $\begin{array}{l}\text { Coefficient } \\
\text { (St. Error) }\end{array}$ & Odds Ratio & $\begin{array}{l}\text { Coefficient } \\
\text { (St. Error) }\end{array}$ & Odds Ratio & $\begin{array}{l}\text { Coefficient } \\
\text { (St. Error) }\end{array}$ & Odds Ratio \\
\hline Age & $\begin{array}{l}0.3177^{*} \\
(0.0645)\end{array}$ & 1.374 & $\begin{array}{l}0.3371^{*} \\
(0.0908)\end{array}$ & 1.401 & $\begin{array}{l}0.3991^{*} \\
(0.1082)\end{array}$ & 1.490 \\
\hline Age Squared & $\begin{array}{l}-0.0033^{*} \\
(0.0007)\end{array}$ & 0.997 & $\begin{array}{c}-0.0038^{*} \\
(0.001)\end{array}$ & 0.996 & $\begin{array}{l}-0.0047^{*} \\
(0.0013)\end{array}$ & 0.995 \\
\hline YSM & - & - & - & - & $\begin{array}{l}-0.0657^{*} \\
(0.0381)\end{array}$ & 0.936 \\
\hline YSM Squared & - & - & - & - & $\begin{array}{l}0.0012^{*} \\
(0.0006)\end{array}$ & 1.001 \\
\hline Guestworker & - & - & - & - & $\begin{array}{l}0.8683^{*} \\
(0.3642)\end{array}$ & 2.383 \\
\hline $\begin{array}{l}\text { Education in } \\
\text { Germany }\end{array}$ & $\begin{array}{c}0.0442 \\
(0.0282)\end{array}$ & 1.045 & $\begin{array}{l}0.1090^{*} \\
(0.0405)\end{array}$ & 1.115 & $\begin{array}{c}0.0377 \\
(0.0392)\end{array}$ & 1.038 \\
\hline $\begin{array}{l}\text { Education before } \\
\text { Migration }\end{array}$ & - & - & - & - & $\begin{array}{c}0.0277 \\
(0.0468)\end{array}$ & 1.028 \\
\hline Disability limits work & $\begin{array}{l}-0.5267^{*} \\
(0.2608)\end{array}$ & 0.591 & $\begin{array}{l}-0.6342 \\
(0.4172)\end{array}$ & 0.530 & $\begin{array}{l}-0.9169 \\
(0.5442)\end{array}$ & 0.400 \\
\hline Married & $\begin{array}{l}-0.6457^{*} \\
(0.2029)\end{array}$ & 0.524 & $\begin{array}{l}-0.0528 \\
(0.2922)\end{array}$ & 0.949 & $\begin{array}{l}-0.1250 \\
(0.3618)\end{array}$ & 0.882 \\
\hline Kids $<16$ in $\mathrm{HH}$ & $\begin{array}{l}0.4744^{*} \\
(0.1885)\end{array}$ & 1.607 & $\begin{array}{c}0.4374 \\
(0.2527)\end{array}$ & 1.549 & $\begin{array}{l}-0.3419 \\
(0.3183)\end{array}$ & 0.710 \\
\hline Own dwelling & $\begin{array}{l}0.4006^{*} \\
(0.1669)\end{array}$ & 1.493 & $\begin{array}{l}0.7479^{*} \\
(0.2254)\end{array}$ & 2.113 & $\begin{array}{l}0.2140 \\
(0.2943)\end{array}$ & 1.239 \\
\hline Financial Worries & $\begin{array}{l}0.6687^{*} \\
(0.2028)\end{array}$ & 1.952 & $\begin{array}{c}0.4287 \\
(0.2490)\end{array}$ & 1.535 & $\begin{array}{c}0.0693 \\
(0.3193)\end{array}$ & 1.072 \\
\hline Feel not belong & - & - & - & - & $\begin{array}{l}-0.4432 \\
(0.3299)\end{array}$ & 0.642 \\
\hline $\begin{array}{l}\text { Want to stay in } \\
\text { Germany }\end{array}$ & - & - & - & - & $\begin{array}{l}-0.0692 \\
(0.2945)\end{array}$ & 0.933 \\
\hline Intercept & $\begin{array}{l}-9.9895^{*} \\
(1.3926)\end{array}$ & - & $\begin{array}{c}-11.5433^{*} \\
(1.8765)\end{array}$ & - & $\begin{array}{c}-10.5976^{*} \\
(2.1698)\end{array}$ & - \\
\hline $\begin{array}{l}\text { AIC } \\
\text { Likelihood Ratio }\end{array}$ & $\begin{array}{r}126 \\
68\end{array}$ & $\begin{array}{l}045 \\
74\end{array}$ & $\begin{array}{c}671 \\
63\end{array}$ & & $\begin{array}{r}502 \\
30\end{array}$ & \\
\hline $\begin{array}{l}\mathrm{N} \\
\mathrm{N} \text { (of self-employed) }\end{array}$ & & & $\begin{array}{c}13 \\
10\end{array}$ & & & \\
\hline
\end{tabular}




\begin{tabular}{|c|c|c|c|c|c|}
\hline & \multicolumn{2}{|c|}{ WEST GERMANS } & \multicolumn{2}{|c|}{ EAST GERMANS } & \multirow{2}{*}{$\begin{array}{c}\text { ALL } \\
\text { IMMIGRANTS } \\
\text { All } \\
\text { W eeklyWages }\end{array}$} \\
\hline & $\begin{array}{l}>1000 \mathrm{DM} \\
\text { per week }\end{array}$ & $\begin{array}{c}<=1000 \mathrm{DM} \\
\text { per week }\end{array}$ & $\begin{array}{c}\text { > } 800 \text { DM per } \\
\text { week }\end{array}$ & $\begin{array}{c}<=800 \mathrm{DM} \\
\text { per week }\end{array}$ & \\
\hline \multirow[t]{2}{*}{ Parameters } & Coefficient & Coefficient & Coefficient & Coefficient & Coefficient \\
\hline & (St. Error) & (St. Error) & (St. Error) & (St. Error) & (St. Error) \\
\hline \multirow[t]{2}{*}{ Age } & $0.0324^{*}$ & $0.0856^{*}$ & $0.0148^{*}$ & $0.0846^{*}$ & $0.1021^{*}$ \\
\hline & $(0.0075)$ & $(0.0126)$ & $(0.0083)$ & $(0.0167)$ & $(0.0102)$ \\
\hline \multirow[t]{2}{*}{ Age Squared } & $-0.0003^{*}$ & $-0.0011^{*}$ & $-0.0002^{*}$ & $-0.0009^{*}$ & $-0.0012^{*}$ \\
\hline & $(0.0001)$ & $(0.0002)$ & $(0.0001)$ & $(0.0002)$ & $(0.0001)$ \\
\hline \multirow[t]{2}{*}{ YSM } & - & - & - & - & 0.0002 \\
\hline & & & & & $(0.0044)$ \\
\hline \multirow[t]{2}{*}{ YSM Squared } & - & - & - & - & 0.00003 \\
\hline & & & & & $(0.0001)$ \\
\hline \multirow[t]{2}{*}{ Guestworker } & - & - & - & - & 0.0245 \\
\hline & & & & & $(0.0360)$ \\
\hline \multirow{2}{*}{$\begin{array}{l}\text { Education in } \\
\text { Germany }\end{array}$} & $0.0383^{*}$ & $0.033^{*}$ & $0.0333^{*}$ & 0.0139 & 0.0058 \\
\hline & $(0.0036)$ & $(0.0129)$ & $(0.0049)$ & $(0.0195)$ & $(0.0053)$ \\
\hline \multirow{2}{*}{$\begin{array}{l}\text { Education before } \\
\text { Migration }\end{array}$} & - & - & - & - & 0.0023 \\
\hline & & & & & $(0.0058)$ \\
\hline \multirow[t]{2}{*}{ Disabilitylimits work } & 0.0108 & $-0.1743^{*}$ & -0.0064 & -0.0072 & $-0.1050^{*}$ \\
\hline & $(0.0261)$ & $(0.0779)$ & $(0.0388)$ & $(0.1006)$ & $(0.0507)$ \\
\hline \multirow[t]{2}{*}{ Hours per week } & $0.0103^{*}$ & $0.0238^{*}$ & $0.0044^{*}$ & $0.0215^{*}$ & $0.0197^{*}$ \\
\hline & $(0.001)$ & $(0.0018)$ & $(0.0011)$ & $(0.0025)$ & $(0.0015)$ \\
\hline \multirow[t]{2}{*}{ Self-employed } & $0.1589^{*}$ & $-0.5388^{*}$ & $0.1475^{*}$ & $-0.5351^{*}$ & $0.2158^{*}$ \\
\hline & $(0.0278)$ & $(0.0773)$ & $(0.0390)$ & $(0.1079)$ & $(0.062)$ \\
\hline \multirow{2}{*}{$\begin{array}{l}\text { Length of time with } \\
\text { firm }\end{array}$} & 0.002 & $0.0136^{*}$ & $0.0044^{*}$ & 0.0005 & $0.0147^{*}$ \\
\hline & $(0.001)$ & $(0.0029)$ & $(0.0014)$ & $(0.0051)$ & $(0.0022)$ \\
\hline \multirow{2}{*}{$\begin{array}{l}\text { Work in Public } \\
\text { Sector }\end{array}$} & $-0.1243^{*}$ & 0.0081 & 0.0150 & 0.0643 & -0.0705 \\
\hline & $(0.0183)$ & $(0.0574)$ & $(0.0256)$ & $(0.0825)$ & $(0.0496)$ \\
\hline \multirow{2}{*}{$\begin{array}{l}\text { Treiman Prestige } \\
\text { Score }\end{array}$} & $0.0069^{*}$ & -0.0019 & $0.0075^{*}$ & 0.0013 & $0.0110^{*}$ \\
\hline & $(0.0008)$ & $(0.0023)$ & $(0.001)$ & $(0.0029)$ & $(0.0014)$ \\
\hline \multirow[t]{2}{*}{ Married } & $0.0652^{*}$ & 0.026 & 0.0372 & 0.0329 & 0.0523 \\
\hline & $(0.018)$ & $(0.0536)$ & $(0.0261)$ & $(0.0733)$ & $(0.0371)$ \\
\hline \multirow[t]{2}{*}{ Intercept } & $5.2341^{*}$ & $3.623^{*}$ & $5.7008^{*}$ & $3.3128^{*}$ & $3.4591^{*}$ \\
\hline & $(0.1672)$ & $(0.2563)$ & $(0.1755)$ & $(0.3406)$ & $(0.2021)$ \\
\hline Dependent Mean & 7.3686 & 6.4869 & 6.9826 & 6.1604 & 6.9385 \\
\hline F Value & 90.61 & 33.77 & 32.41 & 16.63 & 49.16 \\
\hline R Squared & 0.4431 & 0.4647 & 0.3296 & 0.3726 & 0.4425 \\
\hline $\mathrm{N}$ & 1150 & 400 & 670 & 291 & 882 \\
\hline$N$ (of self-employed) & 106 & 40 & 52 & 23 & 51 \\
\hline
\end{tabular}




\section{Wage Distributions of Men in Germany}

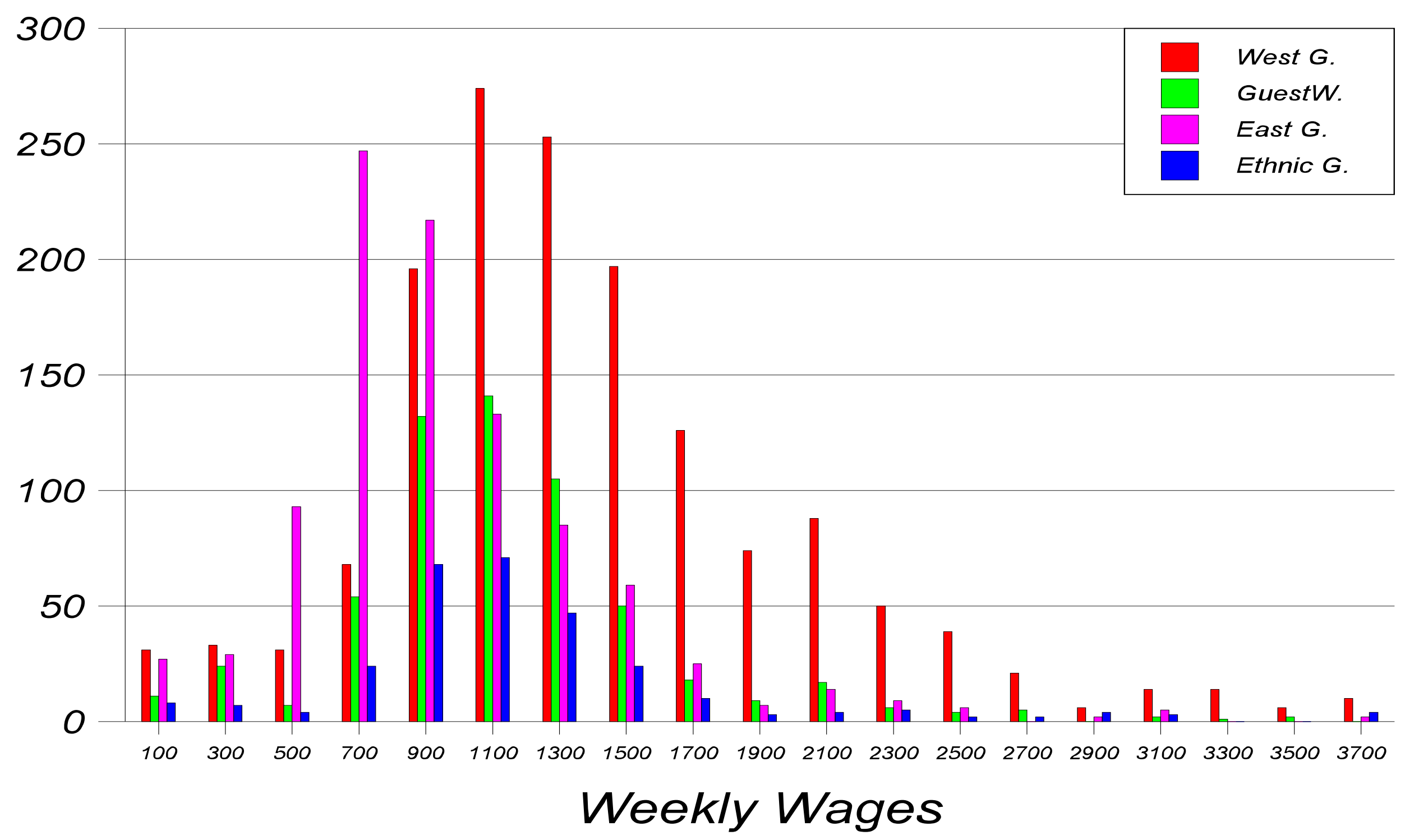




\section{APPENDIX}

TABLE A1. TYPE OF SELF-EMPLOYMENT BY ETHNICITY

\begin{tabular}{ccccc}
\hline & $\begin{array}{c}\text { WEST } \\
\text { GERMANS }\end{array}$ & $\begin{array}{c}\text { EAST } \\
\text { GERMANS }\end{array}$ & $\begin{array}{c}\text { GUEST } \\
\text { WORKER }\end{array}$ & $\begin{array}{c}\text { OTHER } \\
\text { IMMIGR }\end{array}$ \\
\hline $\begin{array}{c}\text { with }<9 \text { co-workers } \\
\text { Independent Farmer }\end{array}$ & 11.39 & 5 & 2.08 & 6.25 \\
$\begin{array}{c}\text { Free-Lance Professional } \\
\text { with }<9 \text { employees }\end{array}$ & 21.78 & 15 & 8.34 & 31.25 \\
with >=9 employees & 1.98 & - & - & - \\
Other Business $\begin{array}{c}\text { with }<9 \text { employees } \\
\text { with >=9 employees }\end{array}$ & 58.42 & 75 & 77.08 & 62.5 \\
Work in Family Business & 1.46 & 4 & 8.33 & - \\
& & 1 & 4.17 & - \\
Number of Observations & & & & 16
\end{tabular}

Note: ${ }^{a}$ The analysis of independent-samples t-test revealed a significant difference between West Germ ans and the other samples

${ }^{b}$ The analysis of independent-samples t-test failed to reveal a significant difference between West Germans and the other samples

Source: Own calculations from GSOEP 2000

TABLE A2. LABOR MARKET CHARACTERISTICS OF EAST GERMANS RESIDING IN EAST GERMANY WITH POSITIVE WAGES

\section{EAST GERMANS}

Monthly Wages (in DM)

3692.46

Weekly Wages (in DM)

923.11

Average weekly hours of work

45.34

Length of time with firm

7.53

Treiman Occupational Prestige Score

40.92

Number of Observations

Source: Own calculations from GSOEP 2000 


\section{IZA Discussion Papers}

\begin{tabular}{|c|c|c|c|c|}
\hline No. & Author(s) & Title & Area & Date \\
\hline 865 & S. W. Polachek & $\begin{array}{l}\text { Mincer's Overtaking Point and the Lifecycle } \\
\text { Earnings Distribution }\end{array}$ & 5 & $08 / 03$ \\
\hline 866 & A. Constant & $\begin{array}{l}\text { Immigrant Adjustment in France and Impacts on } \\
\text { the Natives }\end{array}$ & 1 & $08 / 03$ \\
\hline 867 & $\begin{array}{l}\text { T. J. Dohmen } \\
\text { B. Kriechel } \\
\text { G. A. Pfann }\end{array}$ & $\begin{array}{l}\text { Monkey Bars and Ladders: The Importance of } \\
\text { Lateral and Vertical Job Mobility in Internal } \\
\text { Labor Market Careers }\end{array}$ & 1 & $08 / 03$ \\
\hline 868 & $\begin{array}{l}\text { P. Brañas Garza } \\
\text { S. Neuman }\end{array}$ & $\begin{array}{l}\text { Analyzing Religiosity Within an Economic } \\
\text { Framework: The Case of Spanish Catholics }\end{array}$ & 5 & $08 / 03$ \\
\hline 869 & $\begin{array}{l}\text { A. B. Krueger } \\
\text { A. Mas }\end{array}$ & $\begin{array}{l}\text { Strikes, Scabs and Tread Separations: Labor } \\
\text { Strife and the Production of Defective } \\
\text { Bridgestone/Firestone Tires }\end{array}$ & 3 & $09 / 03$ \\
\hline 870 & $\begin{array}{l}\text { S. Klasen } \\
\text { A. Launov }\end{array}$ & $\begin{array}{l}\text { Analysis of the Determinants of Fertility Decline } \\
\text { in the Czech Republic }\end{array}$ & 4 & $09 / 03$ \\
\hline 871 & $\begin{array}{l}\text { Y. L'Horty } \\
\text { C. Rault }\end{array}$ & $\begin{array}{l}\text { The Impact of Growth, Labour Cost and Working } \\
\text { Time on Employment: Lessons from the French } \\
\text { Experience }\end{array}$ & 5 & 09/03 \\
\hline 872 & $\begin{array}{l}\text { J. R. Munch } \\
\text { M. Rosholm } \\
\text { M. Svarer }\end{array}$ & Are Home Owners Really More Unemployed? & 1 & 09/03 \\
\hline 873 & $\begin{array}{l}\text { M. Falk } \\
\text { B. M. Koebel }\end{array}$ & $\begin{array}{l}\text { The Impact of Office Machinery and Computer } \\
\text { Capital on the Demand for Heterogeneous } \\
\text { Labour }\end{array}$ & 5 & 09/03 \\
\hline 874 & J.-S. Pischke & $\begin{array}{l}\text { The Impact of Length of the School Year on } \\
\text { Student Performance and Earnings: Evidence } \\
\text { from the German Short School Years }\end{array}$ & 6 & $09 / 03$ \\
\hline 875 & C. Grund & $\begin{array}{l}\text { Severance Payments for Dismissed Employees } \\
\text { in Germany }\end{array}$ & 3 & 09/03 \\
\hline 876 & $\begin{array}{l}\text { M. Karanassou } \\
\text { H. Sala } \\
\text { D. J. Snower }\end{array}$ & $\begin{array}{l}\text { The European Phillips Curve: Does the NAIRU } \\
\text { Exist? }\end{array}$ & 3 & $09 / 03$ \\
\hline 877 & M.-S. Yun & Decomposing Differences in the First Moment & 3 & $09 / 03$ \\
\hline 878 & $\begin{array}{l}\text { J. T. Addison } \\
\text { C. Schnabel } \\
\text { J. Wagner }\end{array}$ & $\begin{array}{l}\text { The Course of Research into the Economic } \\
\text { Consequences of German Works Councils }\end{array}$ & 3 & 09/03 \\
\hline 879 & $\begin{array}{l}\text { A. Constant } \\
\text { Y. Shachmurove }\end{array}$ & $\begin{array}{l}\text { Entrepreneurial Ventures and Wage Differentials } \\
\text { Between Germans and Immigrants }\end{array}$ & 1 & 09/03 \\
\hline
\end{tabular}

An updated list of IZA Discussion Papers is available on the center's homepage www.iza.org. 